\title{
Turizm Endüstrisinde Hayvan Kullanımı: Yıkıcı-Yıkıcı Olmayan Temas Temelli Yaklaşım
}

DOI: $10.26466 /$ opus. 925503

\author{
Emirhan Yenișehirlioğlu * - Emine Cihangir ** \\ * Dr.Öğr.Üyesi, Alanya Alaaddin Keykubat Üniversitesi, Antalya/Türkiye \\ E-Posta: emirhan.yenisehirlioglu@alanya.edu.tr ORCID: 0000-0002-6856-9506 \\ ** Dr.Öğr.Üyesi, Van Yüzüncü Yıl Üniversitesi Turizm Fakültesi, Van/Türkiye \\ E-Posta: eminecihangir@yyu.edu.tr ORCID: $\underline{0000-0001-8514-6655}$
}

Öz

Son yıllarda hayvanlarla ilişkilendirilen turizm türlerine olan ilginin giderek artmasıyla birlikte turizm endüstrisinde hayvan kullanımı ve dolayısıyla hayvan etiği konuları yoğun olarak tartışılan konular arasına girmeye başlamıştır. Turistlerin hayvanlara bakışı ve tutumu, gruplar hatta milletler arasında farklılık gösterebilmektedir. Pek çok turist, hayvan kullanımının söz konusu olduğu turizm türlerinin arkasında büyük acıların yaşandığını bilmeden, sadece hayvanları sevdikleri için ilgili turizm hareketliliklerine dahil olabilmektedir. Hayvan refahına ve korunmasına önem veren bu turistler hayvanların kullanıldığ turizm faaliyetlerine katılmakta, talep neticesinde gerçekleşen ticari ilişki de daha fazla hayvanın endüstriye konu olmasına paradoksal olarak sebebiyet vermektedir. Yaşanan bu bilinçli ya da bilinçsiz istismarın önüne geçilebilmesi ve hayvanların endüstri içerisine sürdürülebilir bir algıyla dahil edilmesi gerekliliği, hayvanların turizm endüstrisindeki kullanımının tüm yönleri ile açıkça ortaya koyulması ve incelenmesi ile mümkün olabilir. Bu çalışma turizm endüstrisinin hayvanlar ile iliş̧kisini, turist-hayvan ilişkisinin ortamını ve türünü incelemektedir. Ilgili incelemeler; Turist-hayvan temasının gerçekleştiği alanlar, gerçekleşen temasın yapıcı veya yıkıcı oluşu, hayvanın doğal ortamından koparılıp koparılması̆̆̆ gibi unsurlar üzerinden gerçekleştirilmektedir.

Anahtar Kelimeler: Turizm, Hayvan Hakları, Hayvan Refahı, Hayvan Kullanımı, İnsanHayvan Karşılaşması. 


\title{
Animal Use in the Tourism Industry: Non-Destructive Contact-Based Approach
}

\begin{abstract}
With the increasing interest in tourism types associated with animals, the use of animals in the tourism industry and animal ethics continues to be discussed intensely. The values of tourists can differ between groups and nationalities, but even the tourist's type who care about animal welfare and conservation, paradoxically participate in tourism activities where animals are used. On the other hand, many tourists join animal base attractions just because they love animals, not knowing that there is great pain behind those attractions. It is a necessity to prevent this conscious or unconscious animal abuse in the industry. Understending to all angles of the use of animals in the tourism industry is the key. This study reveals, the use of animals in the tourism industry within the framework of a contact-based approach. This approach might be in a destructive or non-destructive way. it also can be in animal's natural habitat or artificial habitats
\end{abstract}

Keywords: $\quad$ Tourism, Animal Rights, Animal Usage, Human-Animal Encounter 


\section{Giriş}

İnsan-hayvan ilişkilerinin ne zaman başladığı konusunda, elimizde kayda değer bir belge bulunmamaktadır. Ancak, bu ilişkinin modern insanın ortaya çıktığı antropozoik dönemden itibaren başladığı tahmin edilmektedir (Özen, 2015, s.1). Bilinen son küresel buzul çağından - yaklaşık 16.000 yıl öncesinden- günümüze, insan türü gıda ve ham madde ihtiyacının oldukça büyük bir kısmını hayvanlardan ve bitkilerden elde etmiş, hatta antropologlar o günün ekonomik düzenini anlatmak için "avcı ve toplayıcı" kavramını oluşturmuşlardır (Serpell, 1996, s.3). Tarihsel süreç ilerledikçe insanoğlunun hayvanlar ile olan ilişkisinin de ilerlediği ifade edilebilir. Sanayi devrimi öncesine bakıldığında tarım, ulaşım, güvenlik, avlanma, haberleşme gibi alanlarda hayvanların sıklıkla kullanıldığı görülebilmektedir (Sjoberg, 2002; Özen, 2015)

Günümüze, yoğunlukla kabul edilen ana iktisadi düzenin -kapitalizminküresel genişlemesi ve beraberinde gelen bireylerdeki güç, sınıf farkı arayışı süreç içerisinde hayvanlara kadar uzamış ve onların doğal ortamlarından kopartılarak metalaştırılarak, ekonomik bir değer olarak piyasaya sürülmelerine neden olmuştur. (Clark ve Wilson, 2020; Kırlar Can, Ertaş, Yeşilyurt ve Günlü Küçükaltan 2017; Nibert, 2013; Painter, 2016)

Hayvanların insanlar tarafından kullanılması ve haklarının neler olduğu konusunda yıllardır süregelen tartışmalar farklı felsefi ve hukuki yaklaşımlar çerçevesinde tartışılmaya devam edilmektedir. Antroposentrizm (insan merkezli yaklaşım), Fizyosentrizmin (doğa merkezli yaklaşım), Patosentrizm (canlıların ıstırap duyabilme yeteneği) ve Biyosentrizm (canlı olmanın onuru) bu tartışmaların yürütüldüğü teoerik zeminlerden sadece bazılarıdır (Savaş, Yurtman ve Tölü, 2009, s.55).

Hayvanların özel ve kamusal eğlenceler için kullanılması yüzyıllardır insani açıdan sorgulanmamış ve büyük ölçüde göz ardı edilmiş bir uygulamadır. Modern turizm endüstrisi de bu uygulamayı sıklıkla göz ardı etmektedir.

Turizm endüstrisi hayvanları farklı şekillerde metalaştırarak turistik ürün haline dönüştürebilmektedir. Hayvan temelli turizm türlerine olan ilginin gün geçtikçe artmasıyla, turizm endüstrisinde hayvan kullanımı ve hayvan etiği artan bir öneme sahip hale gelmiştir. Ancak, hayvanların kullanılmasına ve haklarına yönelik çeşitli uluslararası yasalar, ilkeler ve çeşitli sivil toplum 
örgütlenmeleri olmasına rağmen (BERN Convention 1979, CITES Convention 1975) turizm endüstrisinde hayvan kullanımı ve hayvan etiği konusundaki bilincin hem tüketim hem de sunanlar tarafında yeterince yerleşmemiş olduğu görülmektedir.

Bu çalışma; turizmde hayvan etiği üzerine yürütülen kuramsal tartışmaları belgesel tarama ile ele alarak, turizm endüstrisinde hayvanların bir ürün olarak kullanımını, hayvanların endüstri içerisindeki refahını ve turist - hayvan ilişkilerini bütünsel bir tartş̧ma ile incelemektedir. Elde edilen veriler ışığında araştırma, turizm ve hayvan kullanımı üzerine yeni bir kavramsal model önerisi ortaya koymaktadır.

\section{Literatür}

Hayvan etiği alanı, hayvan haklarını göz önünde bulunduranlar ile hayvan refahı ile ilgilenen araştırmacılar arasında geniş bir şekilde bölünebilir. Hayvan hakları ve hayvan refahı, insan toplumları için hayvanların etik, politik ve yasal konumlarını kavramanın birbiriyle ilişkili ancak farklı iki yoludur (Calarco, 2020, s.11).

Hayvanların kullanımı üzerine; veterinerlik ve tıp gibi bilim alanlarında deneysel amaçlarla kullanılan hayvanlar açısından hayvan etiği bağlamında büyük tartışmalar yaşanırken (Bennett ve Ringach, 2016; Doke ve Dhawale, 2013; Snyder, Crooks ve Johnston, 2012; Yiğit, Sinmez, Aslım 2015;) gıda sektörüne hizmet eden üretim çiftlikleri boyutu ile hayvan refahı veterinerlik ve ziraat bilimlerinde ağırlıklı incelenmektedir (Dawkins, 2004; Essen, Lindsjö ve Berg, 2020; Fraser, 2009; Hewson, 2003; İzmirli ve Yaşar, 2006; Sandøe ve Christiansen, 2013;). Felsefe ve hukuk bilimlerinde ise hakların, özelde insan ve insan-dışı canlıların haklarının kaynağı, hakların bakılan yer ve bakan tarafından algılanması ve savunulmasındaki farklar gibi ilgili kavramsal boyutlar ortaya konmuştur (Bekoff, 2008; Coeckelbergh ve Gunkel, 2014; Dolmacı ve Bulgan, 2013; Özdağ, 2005; Özgür, 2010; Regan, 2003, Sarıtaş, 2016; Singer, 1975; Yaşar ve Yerlikaya, 2004).

Hayvan hakları veya hayvan refahı gibi etik düşüncelerin gelişimine baktığımızda, Ahlak ve Mevzuata Giriş'te (1789) faydacı felsefesi ile hayvan haklarını tartışan Jeremy Bentham bu alandaki ilk filozof olarak karşımıza çıkmaktadır. Bentham, eylemin faydasını belirlemede kriterlerden biri olarak 
acıyı kullanarak, bir eylem acıya neden oluyorsa sakıncalı olacağını ileri sürmüştür ve asıl sorulması gereken sorunun diğer canlıların akıllı olup olmaması ya da konuşabiliyor olup olmaması değil acı çekebiliyor olup olmadıkları olduğunu belirtir (Aşar, 2018, s. 242; Oliver, 2009, s.39-40,45). Hayvanların etik konumu ve daha özel olarak hayvan hakları üzerine çok sayıda önemli, öncü metinler olmasına rağmen, hayvan etiği konusundaki çağdaş tartışmaların çıkış noktası, Peter Singer'in "Hayvan Özgürleşmesi" (1975) adlı eserinde hayvan çıkarlarını faydacı bir düşünce ile savunmasıdır. Singer, türcülüğü, ırkçlık ve cinsiyetçilikle eşleştirerek, ne ırk ne cinsiyet ne de türlerin ayrımclık için haklı bir neden olamayacağını belirtmektedir (Yount, 2008: 6). Singer (2011), bir varlık acı çekiyorsa, bu acıyı dikkate almayı reddetmenin ahlaki bir gerekçesi olamayacağını ve varlığın doğası ne olursa olsun, eşitlik ilkesi, başka herhangi bir varlıkla benzer ıstırapla eşit olarak sayılmasını gerektiğini ifade etmektedir. Ancak bir varlık acı çekmeye, zevk veya mutluluğu deneyimlemeye muktedir değilse, dikkate alınacak hiçbir şey olmayacağına vurgu yapmaktadır (s.50). Singer (1975), hayvan ve insan hakları belirlenirken eşitliğin temel ilkesini, eşit veya özdeş muameleyi gerektirmediğini ancak eşit düşünmeyi gerektirdiğini ifade eder. Singer'in, pragmatik ya da faydacı yaklaşımından kaçınan Regan, (1984) "Hayvan Hakları Davası" eserinde hayvanlarda acıya neden olan tüm insan kullanımlarının ahlaki açıdan yanlış olduğunu ve insanlara ne kadar fayda sağlasa da kaldırılması gerektiğini belirtir (Regan, 1984 aktaran Yount, 2008, s.5-7). Aslında, bir hayvanın hayatının acısız bir şekilde sona erdirebileceğini iddia etmek ahlaki bir değer taşımamaktadır, çünkü acısız bir şekilde yapılabilse bile bir hayvanın hayatının sona ermesini isteyeceğini (kendi hayatımızın sona ermesini istemeyeceğimiz gibi) varsaymaya hakkımız yoktur (Newmyer, 2006, s.49). Regan (2003), hayvan haklarına ilişkin soruların, seçimlerimiz ve günlük yaşam tarzımızın ahlaki envanterini çıkarmaya zorlayan bir sorgulama olduğunu ifade etmektedir. Eğer hayvanların hakları yoksa o zaman insanların onları sömürme yollarının hiçbirinin (gıda kaynağı veya giyim için) prensipte yanlış olmayacağını diğer yandan, eğer hayvanların hakları varsa, o zaman onları sömürmemizin tüm biçimlerinin ilke olarak yanlış olduğunu ve derhal durdurulması gerektiğini belirtir (s.xii ). Singer (1975) ve Regan (2004), modern hayvan hakları hareketinin felsefinin temelini oluşturmakta ve görüşlerini modern seküler nedenlere dayandırarak etiğin nesnel olduğunu, köklerinin 
akla dayandığını savunmaktadırlar. Her ikisi de analitik etik yöntemleri ile hareket etmektedirler (Sherry, 2009, s.11).

Hayvan refahı alan yazında çok farklı şekillerde ele alınmış, tanımlanmış ve ölçülmeye çalışılmıştır. Hayvan refahı genellikle bir hayvanın zevkini, mutluluk durumunu, gelişme yeteneğini ve doğal ortamında doğal bir yaşam tarzı yaşama özgürlüğünü içerir. Hayvan refahı savunucuları, bir bütün olarak hayvanlar veya türler için refahın bu yönlerinden herhangi birini veya bir kombinasyonunu sağlamaya çalışılar (Calarco, 2020, s.11). Hewson (2003) ise hayvan refahının doğal yaşam, fizyoloji ve duygularının (zihinsel/davranış) ne ölçüde karşılandığını içermesi gerektiğini savunmuştur (s.496-497). Dawkins'e (2004) göre, refah hayvanların istediklerine sahip olup olmadıklarına ve mutlu olup olmadıklarına göre tanımlanmalıdır (s.941). Duncan (2005), refahı tanımlarken, hayvanların bütünsel olarak zihinsel ve fiziksel sağlığı, çevresi ile uyumu, insan tarafından sağlanan yapay bir ortama acı çekmeden uyum sağlayabilmesi ve bir şekilde duygularının dikkate alınması gerektiğini belirtmiştir (s.484). Fraser (2009), hayvan refahı odağını üç genel hedef üzerinden tanımlamıştır; hayvanların fiziksel sağlığının devamı, hoş olmayan duygusal durumlarını (ağrı, korku gibi) en aza indirmek ve doğal gelişim ve yaşamlarını sürdürmeleri (s.507). Turizm özelinde ise Fennell (2013), turizme konu olan hayvanların refah ihtiyaçlarını daha ciddiye almak amacıyla araştırma programları başlatmanın acil bir ihtiyaç olduğunu ifade etmiştir (s.336).

Tip, veterinerlik ve ziraat endüstrileri dışında farklı endüstrilerde de insanlara çeşitli faydalar sağlamak üzere hayvanların kullanılması günümüzde yoğun tartışılmalara neden olmaktadır. Hayvanların kullanımında önemli endüstrilerden biri olan turizm endüstrisinde hayvan hakları ve hayvan etiği konularına ilişkin çalışmalar ile uzun yıllardır dünya genelinde tartışlıyor olmasina rağmen (Bertella, 2016; Crang, 2015; Fennell, 2013, Malloy ve Fennell, 1998; Rollin, 1981, Shani, 2009; Shani ve Pizam, 2008; Sneddon, Lee, Ballantyne ve Packer, 2016; Winter, 2020), ülkemizde konuya ilişkin son yıllarda sınırlı sayıda çalışma olduğu alan yazın taramasında görülmüştür. Küçükaltan ve Dilek'in (2017) “Metalaşan Turizm" derleme çalışmaları içinde "Kapitalizm-Turizm ve Metalaştırdıkları", "Turizmin Ahlaki Sorumluluğu ve Hayvanlar Sorunsalı", "Vegan ve Vejetaryen Turistler", "Hayvanlar Üzerinden Yaratılan Turistik Ürün Çeşitleri” “Sorumlu Turizm ve Hayvan Refahı”; “Tu- 
rizm Cazibe Merkezleri ve Hayvan Kullanımı"; "Turistik Etkinlikler -Festivaller- ve Hayvanlar", "Turistik Deneyime Hayvanların Dâhil Edilmesi" ve "Evcil Hayvan Sahiplerinin Turizme Katılım Sorunları" yer almıştır. Dilek ve Küçükaltan (2018) Türkiye'de yer alan hayvan odaklı turizm işletmelerinin yönetici ve ziyaretçileri ile görüşerek, turizmin arz ve talep boyutunda hayvanlara yönelik nasıl bir ahlaki sorumluluğa sahip olunması gerektiğini araştırmışlardır. Küçükaltan ve Dilek (2019) turizmin metalaşmış hayvanlar için ne anlama geldiğinin felsefi temelini ele almışlardır. Harman ve Dilek (2017) balina gözlemcilerinin deneyimlerini yorumladıkları bir seyahat forumunu incelemiş ve izleyicilerin duyusal izlenim, duygusal yakınlık, yansıtıcı tepki ve davranışsal tepkilerini ortaya koymuşlardır. Adıgüzel (2018), turizm sektöründe çalıştırılan hayvanlar ve uğradıkları hak ihlallerini, Türkiye örnekleri üzerinden ilgili yasalar çerçevesinde incelemiştir.

$\mathrm{Bu}$ çalışmaların dişında ülkemizde hayvanların yer aldığı çalışmaların önemli bir bölümü hayvan hakları boyutundan ziyade somut olmayan kültürel mirasın yaşatılmasına vurgu yapmaktadır. Deve güreşleri ve boğa güreşleri gibi hayvanların ana obje olduğu organizasyonların devamlılığını sağlamanın önemine ve gerekliliğine değinen bu çalışmalar, böylece hem kültürel mirasın korunacağına hem de yerel ekonomilerin güçleneceğini ifade etmektedirler (Akar, 1994; Atasoy ve Özbaşer, 2014; Çalışkan, 2010; Çulha, 2008; Erdem, 1998; Kılıçkıran, 1987; Yakut, 2009; Yılmaz ve Ertuğrul, 2015). Bir diğer hayvan odaklı turizm türü olan av turizmi uygulamaları, potansiyeli ve kırsal turizm açısından kırsal kalkınma üzerindeki etkilerinin ortaya konulduğu çalışmalar (Özer, 2020; Şafak, 2003; Ulusoy, 2015;) ile hayvan etiğinin (Çalık ve Çiftçi, 2013) ele alındığı çalışmalar turizm literatüründe yer almaktadır.

\section{Turizm Endüstrisinde Hayvan Kullanımı}

Dünya üzerinde seyahat eden turistlerin $\% 40-\% 60$ arasındaki bir oranı doğal hayata ilgi duymakta ve bu amaçla seyahatlerini gerçekleştirmektedir. Hayvanların bazı destinasyonların başlıca turistik simgelerini oluşturması ve yaban hayat turizminin artan popülaritesi nedeniyle doğal hayata ilgi duyan turistlerin \%20-\%40 arasında bir oranı doğrudan vahşi yaşam ile temas kurma amacı ile seyahatlerini gerçekleştirmektedir (Reynolds ve Braithwaite, 2001). Dünya Seyahat ve Turizm Konseyi 2018 yılı "Küresel Yaban Hayatı 
Turizminin Ekonomik Etkisi" raporuna göre yaban hayatı turizmi küresel GSYİH'ya 120,1 milyar dolar doğrudan katkıda bulunarak tüm doğrudan turizm GSYİH'sinin \%4,4'ünü oluşturarak ve Dünya çapında hayvanları doğal ortamlarında görmeyi ve deneyimlemeyi içeren doğrudan 9,1 milyon iş sağlamıştır (World Travel ve Tourism Council [WTTC], 2019)

Birçok destinasyonda yaban hayatı turistik cazibe merkezlerini ziyaret etmek başlıca turist motivasyonudur (Higginbottom, 2004). Hayvanların turizm deneyiminde oynadıkları rol ve turist-hayvan karşılaşmaları çok farklı şekillerde olabilmektedir (Carr ve Broom, 2018, s.26). World Animal Protection tarafından yapılan araştırma, turistlerin \%93'ünün hayvan sevgisinden dolayı cazibe merkezlerini ziyaret ettiklerini ortaya koymaktadır (Kinder, 2019). Dünya genelinde milyonlarca hayvan tutsak edilirken diğerleri kültürel olarak onaylanmış taciz ritüellerinde öldürülmektedirler (Winter, 2020, s.1). Araştırmacılar, 230.000 ila 550.000 arasında hayvanın, refahları üzerinde zararlı bir etkiye sahip cazibe merkezlerinde tutulduğunu tahmin etmektedirler. Bunun yanında, refah ve koruma üzerinde yararlı etkileri olması muhtemel olan yalnızca 1.500 ila 13.000 hayvan, turistik yerlerde tutulmaktadır. Fil gezintileri, ayı barınaklanı, deniz kaplumbağası çiftlikleri, timsah çiftlikleri, ayı safra çiftlikleri ve köpekbalığı kafesi dalışları en fazla sayıda hayvanın tutsak olduğu (500.000'den fazla) merkezlerdir (Tourism Concern, 2017) Turizmde teşhir ve eğlence için esir olarak, hamal ve taşıyıcı olarak, av olarak, ayrıca rekabet ve spor amaciyla kullanılan hayvanların sayısının belirlenmesi ise oldukça zordur (Fennell, 2013, s.330).

\section{Turizm Endüstrisinde Hayvan-İnsan Etkileşimleri}

Turizmde endüstrisi vahşi, yarı vahşi veya esir hayvanları doğal ya da insan yapımı ortamlarda, pasif izleme veya aktif etkileşim sunan bir dizi etkinlik dahil olmak üzere çeşitli insan-hayvan etkileşimleri bağlamında kullanmaktadır. Turist-hayvan etkileşimlerinin gerçekleştiği ortamların önemli ölçüde heterojen olması, bu tür ortamların çeşitli özelliklerini yakalayabilen kullanışlı ve kapsamlı bir tipolojiyi gerektirmiştir (Essen vd., 2020; Shani, 2013, s. 104) Tablo 1'de araştırmacıların ağırlıklı olarak turizm bağlamında insanhayvan etkileşimleri sınıflandırmalarına yer verilmiştir. 
Tablo. 1 Turizm bağlamında insan-hayvan etkileşimleri

\begin{tabular}{|c|c|c|}
\hline $\begin{array}{l}\text { Duffus ve } \\
\text { Dearden } \\
(1990)\end{array}$ & $\begin{array}{l}\text { - Tüketen Kullanım } \\
\text { - Az Tüketen Kulla- } \\
\text { nım } \\
\text { - Tüketmeyen Kulla- } \\
\text { nım }\end{array}$ & $\begin{array}{l}\text { Tüketen ilişkide hayvanların direk ya da ölü- } \\
\text { müne yol açan etkileşimler yer almakta. Düşük } \\
\text { tüketimde; hayvanat bahçeleri, akvaryumlar } \\
\text { gibi tesisler tüketim amaçlı olmayan kuş göz- } \\
\text { lemciliği, balina izleme gibi. }\end{array}$ \\
\hline $\begin{array}{l}\text { Orams } \\
(1996)\end{array}$ & $\begin{array}{l}\text { - Tutsak } \\
\text { - Yarı Tutsak } \\
\text { - Vahşi }\end{array}$ & $\begin{array}{l}\text { Hayvan temelli ziyaretçi cazibe merkezleri Tu- } \\
\text { rist-Yaban Hayatı Etkileşim Fırsatları Spekt- } \\
\text { rumu (SoTWIO); Tutsak etkileşim, yaban haya- } \\
\text { tını esir tutan ve gözlemi kolaylaştıran hayva- } \\
\text { nat bahçeleri ve akvaryumlar, sirkler gibi tesis- } \\
\text { lerde gerçekleşir. Yarı tutsak etkileşim, doğal } \\
\text { çevreyi simüle eden veya bir kısmını kullanan } \\
\text { safari parkları, deniz yaban hayatının görülebil- } \\
\text { diği ve bazı durumlarda turistlerin onlarla yüz- } \\
\text { melerine izin verilen geniş su alanları gibi nis- } \\
\text { peten doğal bir çevre ve az sayıda insan yapımı } \\
\text { yapı veya etki ile karakterize edilir. Vahşi etki- } \\
\text { leşim ortamı; hiçbir şekilde kısıtlanmayan hay- } \\
\text { vanlar ile karakterize edilir. Milli parklar veya } \\
\text { deniz alanları gibi. }\end{array}$ \\
\hline $\begin{array}{l}\text { Shackley } \\
\text { (1996) }\end{array}$ & $\begin{array}{l}\text { - Hareket Kısıtlaması } \\
\text { (Tam Kapalılık } \rightarrow \\
\text { Tam Özgürlük) } \\
\text { X } \\
\text { - Cazibe Motivasyonu } \\
\text { (Koruma/Eğitim } \rightarrow \\
\text { Eğlence) }\end{array}$ & $\begin{array}{l}\text { Hayvan temelli cazibe merkezlerini, hayvanla- } \\
\text { rın hareket kısıtlamasına ve bu cazibe merkez- } \\
\text { lerinin işleyişinin arkasındaki motivasyona } \\
\text { göre sınıflandırmıştır. Esaret ortamlarında hay- } \\
\text { vanların; hareket kısıtlamasını "tam kapalılık" } \\
\text { "tam özgürlük" skalasına ve ortamın cazibe } \\
\text { motivasyonunu; "koruma/eğitim" "eğlence" } \\
\text { skalasına göre ayırmıştır. Örneğin, akvaryum- } \\
\text { lara baskın bir koruma/eğitim ile yüksek hare- } \\
\text { ket kısıtlaması bölgesinde yer vermiştir. Sirkler } \\
\text { ise baskın bir eğlence yönelimi ile yüksek hare- } \\
\text { ket kısıtlaması alanında yer alır. }\end{array}$ \\
\hline $\begin{array}{l}\text { Bullbeck } \\
\text { (1999) }\end{array}$ & $\begin{array}{l}\text { - Otantik } \\
\text { - Yarı Otantik } \\
\text { - Aşamalı }\end{array}$ & $\begin{array}{l}\text { Birincisi otantik alanlar "vahşi" hayvanların dü- } \\
\text { zenli olarak ziyaret ettiği turistik yerlerdir. İkin- } \\
\text { cisi yarı otantik karşılaşma alanları, safari türü } \\
\text { bir gezinti deneyimi sunan ve çeşitli barınaklar } \\
\text { içerebilen. Üçüncüsü "aşamalı" karşılaşma } \\
\text { alanları, hayvanların küçük muhafazalardan ve } \\
\text { parmaklıklardan görüntülenen deneyimleri içe- } \\
\text { rir. }\end{array}$ \\
\hline
\end{tabular}




\begin{tabular}{|c|c|c|}
\hline $\begin{array}{l}\text { Reynolds ve } \\
\text { Braithwaite } \\
(2001)\end{array}$ & $\begin{array}{l}\text { - Genel Erişim } \\
\text { - Yaratılmış Dene- } \\
\text { yimler } \\
\text { - Sinırlı Erişim } \\
\text { - Kısıtlı Erişim }\end{array}$ & $\begin{array}{l}\text { Yaban hayatı turizminde ziyaretçilerin hayvan- } \\
\text { lara erişiminin çevresel ve turist memnuniyeti } \\
\text { açısından cazibe bağlamlarını farklı düzeylerde } \\
\text { yansıtan üç sınıflandırma yapmıştır. Genel eri- } \\
\text { şim; hayvanlar kendi yaşam alanlarında ve do- } \\
\text { ğal davranışlar sergilemelerine rağmen, yüksek } \\
\text { yoğunlukta cazibe kullanım alanlarında bir mik- } \\
\text { tar alışkanlık gösterebilmektedirler. Milli park- } \\
\text { lar, vahşi alanlar gibi. Yaratılmış deneyimler: } \\
\text { hayvanat bahçeleri, sirkler, vahşi yaşam park- } \\
\text { ları, evcil hayvanlar. Etkileşim yapmacıktır, ya- } \\
\text { ratılmıştır. Hayvanlar doğal ortamlarında değil- } \\
\text { dir ve çok az hayvan ancak çok sayıda insan var- } \\
\text { dır. Sınırlı erişim, nadir hayvanlar: Doğal ortam- } \\
\text { daki hayvanlar ile ziyaretçi, az bulunan hayvan- } \\
\text { lar ile yakın bir etkileşim arzular. Kısıtlı erişim, } \\
\text { nadir/nesli tükenmekte olan hayvanlar: doğal } \\
\text { ortamdaki bu hayvanlar ile yüksek fiziksel } \\
\text { ve/veya parasal maliyete neden olacak ilişkiler- } \\
\text { dir. }\end{array}$ \\
\hline $\begin{array}{l}\text { Beardsworth } \\
\text { ve Bryman } \\
(2001)\end{array}$ & $\begin{array}{l}\text { - Karşılaşma } \\
\text { - Temsil } \\
\text { - Sunum } \\
\text { - Yapay Deneyim- } \\
\text { leme }\end{array}$ & $\begin{array}{l}\text { İnsan-hayvan etkileşimlerini vahşi hayvan bo- } \\
\text { yutunda karşılaşma, temsil, sunum, yapay dene- } \\
\text { yimleme olarak dört şekilde ayırmaktadır. Kar- } \\
\text { şılaşma; bir anlamda, en dolaysız olanıdır. Bire- } \\
\text { yin, bir veya daha fazla duyu aracılığılla algıla- } \\
\text { nabilmesi için aslında kendi ortamında sınırlan- } \\
\text { dırılmamış hayvanın fiziksel mevcudiyetinde } \\
\text { olmasını gerektirir. Temsil; vahşi hayvanların fi- } \\
\text { güratif temsili, vahşi yaratıkların edebi, sanatsal } \\
\text { ve sembolik açıdan ve davranışlarının grafik ve } \\
\text { dramatik görsel ve işitsel temsillerini içermekte- } \\
\text { dir. Sunum; hayvanın algısı bakımından karş1- } \\
\text { laşmadan farklıdır. Yapay deneyimleme; yapa- } \\
\text { yın yaratılmasını gerektirir, ancak izleyenleri } \\
\text { gerçek olduklarına inanması için aldatmayı } \\
\text { amaçlayan sahtelerin yaratılmasını gerektirmez. } \\
\text { Amaç, izleyicinin "şakaya dahil" olması ve yap- } \\
\text { nın becerisi, kapsamı veya ölçeği tarafından } \\
\text { yönlendirilmesi, eğlendirilmesi ve etkilenmesi- } \\
\text { dir. }\end{array}$ \\
\hline
\end{tabular}




\begin{tabular}{|c|c|c|}
\hline $\begin{array}{l}\text { Hall, Roberts, } \\
\text { Wemelsfelder } \\
\text { ve Farish } \\
(2003)\end{array}$ & $\begin{array}{l}\text { • Doğal/ Yarı Doğal } \\
\text { Ortam Keşif ve Gö- } \\
\text { rüntüleme Vahşi } \\
\text { Hayvanlar } \\
\text { • Yapay Ortamda } \\
\text { Sergilenen 'Nesne- } \\
\text { ler' Olarak Vahşi } \\
\text { Hayvanlar } \\
\text { • Etkileşim ve Keşif } \\
\text { Amaçlı Evcilleştiril- } \\
\text { miş/ Uysal Hayvan- } \\
\text { lar (Tutsak-Yarı } \\
\text { Tutsak) } \\
\text { - Spor Temelli Rekre- } \\
\text { asyon İçin Vahşi } \\
\text { Hayvanlar }\end{array}$ & $\begin{array}{l}\text { Hayvan temelli cazibe merkezleri deneyimsel } \\
\text { olarak sınıflandırılmıştır. Birincisi a) Bu tür hay- } \\
\text { vanlarla doğal veya yarı doğal ortamlarda ziya- } \\
\text { retçilerden uzakta ve çok az dokunsal temas. } \\
\text { Hayvanların potansiyel 'tehlikesi', 'vahşiliği' ve } \\
\text { 'tehdidi' temel bir çekim olabilir. Uzaktan izleme, } \\
\text { fotoğrafçılık, heyecan, tehlike, az sayıda insan. b) } \\
\text { Yarı doğal ortamlar -yaban hayatı parkları, yaban } \\
\text { hayatı rehabilitasyon merkezleri, kuş barınakları, } \\
\text { büyük şehir parkları. Daha küçük ölçektedirler. } \\
\text { 'Vahşilik' az ancak ziyaretçilerin deneyimi ben- } \\
\text { zerdir. İzleme, fotoğrafçllı, daha yakından } \\
\text { görme, güvenlik. İkincisinde, genellikle cinse, } \\
\text { ekolojik nişe veya coğrafi kökene göre 'düzenlen- } \\
\text { miş' sergi nesneleri olarak hayvanların açı su- } \\
\text { numu: hayvanat bahçeleri, akvaryum, yunus, ke- } \\
\text { lebek merkezleri ve 'vahşi yaşam' merkezleri. Kü- } \\
\text { çük bir macera veya keşif söz konusu. Risksiz ya- } \\
\text { kından görmeyi sağlayan fiziksel engeller mev- } \\
\text { cut. Hayvanlar, eğlence ve eğitim amaçlı sunulur. } \\
\text { Küçük bir alanda birçok tür yakından görülür; } \\
\text { çok sayıda insan; eğlence, eğitim, bazıları yerli } \\
\text { ancak genellikle egzotik, uzman türler veya yay- } \\
\text { gın çeşitli türler. Üçüncü grup, bu tür hayvanla- } \\
\text { rın 'güvenli', 'sevimli' varsayılarak çocukları he- } \\
\text { def alır. Boş zaman aktivitesi, binicilik, çocuk çift- } \\
\text { liği, hayvan barınakları, ulaşım sağlayan hayvan- } \\
\text { lar gibi çiftlik 'sunumları' buraya dahil edilmiştir. } \\
\text { Son grup: ateş etmek, avlanmak, yarışmak veya } \\
\text { balık tutmak için hedef olarak kullanılan hayvan- } \\
\text { lardır. Yerli, egzotik, vahşi veya yarı tutsak olabi- } \\
\text { lir. Heyecan, potansiyel tehlike ve sosyallik, ra- } \\
\text { hatlama ve yalnızlık. }\end{array}$ \\
\hline $\begin{array}{l}\text { Higginbottom } \\
(2004)\end{array}$ & $\begin{array}{l}\text { - Yaban Hayatı Göz- } \\
\text { lemciliği } \\
\text { - Esir-Vahşi Yaşam } \\
\text { Turizmi } \\
\text { - Avcılık Turizmi } \\
\text { • Balıkçılık Turizmi }\end{array}$ & $\begin{array}{l}\text { Yaban hayatı gözlemciliği turizmi; serbest dola- } \\
\text { şan hayvanların görülmesi veya başka bir şekilde } \\
\text { etkileşimde bulunulması. Esir-vahşi yaşam tu- } \\
\text { rizmi; hayvanları insan yapımı hapishanelerde } \\
\text { görmeyi içerir. Hayvanat bahçeleri, vahşi yaşam } \\
\text { parkları, hayvan barınakları, akvaryumlar; sirk- } \\
\text { ler ve gösteriler gibi. Avcılık turizmi ve balıkçllık } \\
\text { turizmi olarak ayırmıştır. }\end{array}$ \\
\hline
\end{tabular}




\begin{tabular}{|c|c|c|}
\hline $\begin{array}{l}\text { Cohen } \\
\text { (2009) }\end{array}$ & $\begin{array}{l}\text { - Tamamen Doğal } \\
\text { Ortamlar } \\
\text { - Yarı Doğal Ortam- } \\
\text { lar } \\
\text { - Yarı-Yapay Ortam- } \\
\text { lar } \\
\text { - Tamamen Tasarlan- } \\
\text { miş Ortamlar }\end{array}$ & $\begin{array}{l}\text { Hayvan-insan etkileşimi hayvanların kısıtlan- } \\
\text { ması bağlamında ele alınmıştır. Tamamen doğal } \\
\text { ortamlar; çerçevelenmemiş, vahşi hayvanların } \\
\text { hiçbir şekilde kısıtlanmadığı vahşi doğa, orman- } \\
\text { lar çöller. Yarı doğal ortamlar; sınırlandırılmıs, } \\
\text { ancak yönetilen alanlar. Hayvanların, ortamın sı- } \\
\text { nırları içindeki doğal yaşam alanlarında sınırsız } \\
\text { yaşamaya devam ettikleri varsayılıyor, milli } \\
\text { parklar ve vahşi yaşam koruma alanları. Yarı-ya- } \\
\text { pay ortamlar; tutsak hayvanların, doğal yaşam } \\
\text { alanları simüle edilerek oluşturulan ortamlar. } \\
\text { Hayvanat bahçeleri, akvaryumlar, hayvan temalı } \\
\text { parklar. Tamamen tasarlanmış ortamlar; vahşi } \\
\text { görünmelerine rağmen tutsak hayvanların farklı } \\
\text { derecelerde evcilleştirildiği, eğitildiği veya insan- } \\
\text { laştırıldığı hayvan performansları, şovları. }\end{array}$ \\
\hline $\begin{array}{l}\text { Fennell } \\
\text { (2012) }\end{array}$ & $\begin{array}{l}\text { - Esirler } \\
\text { - Turizm İşçisi } \\
\text { - Oyuncu Hayvanlar } \\
\text { - Spor Amaçlı Avcılık } \\
\text { - Yaban Hayatı İz- } \\
\text { leme }\end{array}$ & $\begin{array}{l}\text { Turizm faaliyetlerinde esir olan hayvanlar; temel } \\
\text { motivasyonu izlemekten türetilen zevk ve eğ- } \\
\text { lence değeri olan kitle için farklı biçimlerde sunu- } \\
\text { lurlar. Turizm endüstrisi işçisi hayvanlar, ye- } \\
\text { rinde veya doğal ortamında seyahat deneyimle- } \\
\text { rini gerçekleştiren veya kolaylaştıran türler. Kav- } \\
\text { gaya ve rekabete zorlanan hayvanlar, hayvan dö- } \\
\text { vüşleri, kan, cesaret gösterisi ve bahis sporla- } \\
\text { rında 'oyuncu' olan hayvanlar. Spor için avlanan } \\
\text { hayvanlar. Yaban hayatın izlenmesi için yürütü- } \\
\text { len turizm faaliyetlerinde olanlar. }\end{array}$ \\
\hline $\begin{array}{l}\text { Moscardo } \\
(2013)\end{array}$ & $\begin{array}{l}\text { - Geleneksel Tutsak } \\
\text { - Geleneksel Olma- } \\
\text { yan Tutsak } \\
\text { • Tedarik Edilmiş (İn- } \\
\text { san) } \\
\text { - Tedarik Edilmiş } \\
\text { (Doğal) } \\
\text { - Esaret Altında Ol- } \\
\text { mayan Ortam-Bol } \\
\text { Yaban Hayatı } \\
\text { - Esaret Altında Ol- } \\
\text { mayan Ortam-Na- } \\
\text { dir/Görülmesi Zor } \\
\text { Yaban Hayatı }\end{array}$ & $\begin{array}{l}\text { Yaban hayatına dayalı turizm faaliyetleri ve in- } \\
\text { san-hayvan karşılaşmaları, faaliyetin tek bir türe } \\
\text { veya birden çok türe odaklanmasına, deneyimin } \\
\text { yoğunluğuna ve yaban hayatının türüne bağl1 } \\
\text { değişiklik gösterebilmektedir. Geleneksel tutsak- } \\
\text { tan, esaret altında olmayan ortama (nadir/görül- } \\
\text { mesi zor yaban hayatı) giden şekilde sınıflandır- } \\
\text { mıştır. Sınıflandırmanın bir ucunda hayvanat } \\
\text { bahçeleri ve daha küçük muhafazalara sahip ak- } \\
\text { varyumlar gibi geleneksel esir ortamları, diğer } \\
\text { ucunda ise nadir olmaları veya görülmesi zor } \\
\text { olabilecek serbestçe dolaşan vahşi yaşamın ol- } \\
\text { duğu doğal ortamlar temsil edilir. }\end{array}$ \\
\hline
\end{tabular}




\section{Turizm Endüstrisinde Hayvan Kullanımı: Yıkıc1-Yıkıcı Olmayan Temas Temelli Yaklaşım}

Turizm endüstrisinde hayvanların kullanıma yönelik ilişkisini ortaya koymayı hedeflediğimiz modelin ilk basamağında "Doğrudan Temas" ve "Dolaylı Temas" ilişkisi bağlamında ayrım yapılmıştır. Turistlerin tüketimi çerçevesinde hayvanların turistik ürün olarak kullanımları turist-hayvan teması bağlamında ele alınmaya çalışılmıştır. Yaklaşımda hayvanlarla dolaylı veya dolaysız temas bağlamında temel alınan nokta, turistlerin bilinçli ya da bilinçsiz olarak hayvanları turistik ürün olarak kullanmalarının hayvan yaşamı ve refahı üzerinde yıkıcı etki yaratıp yaratmadığıdır. Görsel 1.'de “Temas Temelli Hayvan Kullanımı İlişkisi" yer almaktadır.

I. Doğrudan Temas: Doğrudan temas grubunda, turistlerin hayvanlar ile fiziksel olarak temaslarının olduğu veya olma ihtimalinin olduğu düşünülmektedir. Bu temaslar, hayvanların doğal ortamında gerçekleşebileceği gibi doğal ortamından kopartılmış veya zaten doğal ortamında doğmamış bir hayvanın insan eliyle yaratılmış doğala benzeşik bir ortamda gerçekleşebilmektedir. Bu süreçlerin bir turizm hareketliliği içinde birbirinden kesin s1nırla ayılmadığı, eş zamanlı ya da karmaşık bir şekilde gerçekleştiği veya sadece bir tanesini içerebildiği görülebilmektedir. Bu bağlamda bir hayvana dokunmak, sevmek, beslemek ya da taşıma amaçlı kullanmak bir temas türü olabileceği gibi, av turizmine konu olan faaliyetlerin de bu kapsamda ele alınması gerekmektedir. Örneğin av izni verilmiş yaban hayvanlarını avlamak veya sportif amaçlı balık tutmak gibi amaçlar ile seyahat eden bir turist kitlesinden söz etmek mümkünken, aynı zamanda sadece vahşi yaşamı gözlemleyebilme motivasyonuyla seyahat gerçekleştiren bir kitleden de söz etmek mümkündür (Higginbottom, 2004; Tremblay, 2001). 


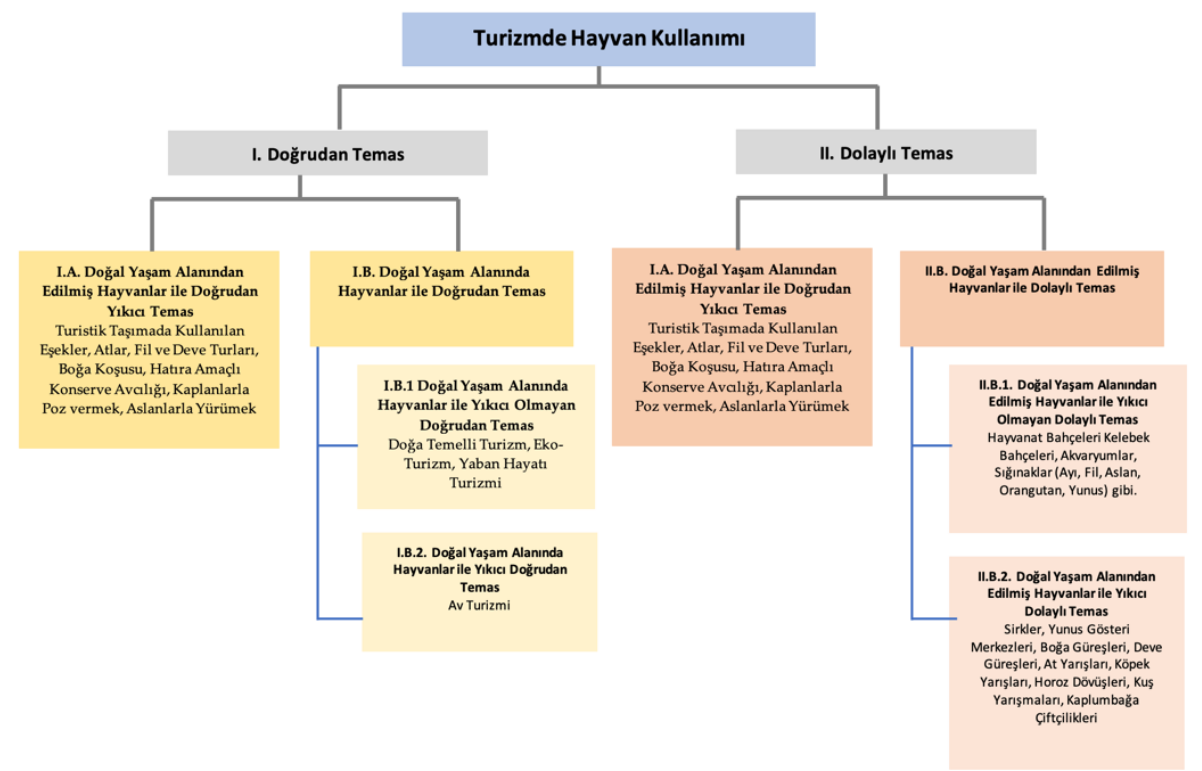

Şekil 1. Temas Temelli Hayvan Kullanımı İlişkisi

“Doğrudan Temas” “Doğal Yaşam Alanından Edilmiş Hayvanlar ile Doğrudan Yıkıcı Temas" ve "Doğal Yaşam Alanında Hayvanlar ile Doğrudan Temas" olarak iki gruba ayrılmakta ve Doğal Yaşam Alanında Hayvanlar ile Doğrudan Temas ise "Yıkıcı Olmayan ve Yıkıcı Olan Temas" olarak ele alınmaktadır.

\section{I.A. Doğal Yaşam Alanından Edilmiş Hayvanlar ile Doğrudan Yıkıcı Temas:} grubunda yer alan turist kitlesi ve sunulan turizm faaliyetleri incelendiğinde, hayvanlarla doğrudan temas eden ve bu teması sürdürmeyi bilinçli tercihleri ile destekleyen ancak asıl amaçları hayvanları doğal yaşamlarında gözlemlemek olmayan bir kitleden söz etmek gerekmektedir. Bu kitlenin talep ettikleri ana turistik ürünün bir kısmi ya da ağırlıklı bir parçasında, doğal ortamından edilmiş ve metalaştırılmış hayvanların kullanılması söz konusudur. Bu grupta yer alan faydalanmalar, hayvanları doğal yaşam alanlarında uzaklaştırılan, doğal yaşama hakları elinden alınan hayvanları ve hayvan etiğine aykırı tüm faydalanmaları kapsamaktadır ve çok yıkıcıdır.

Bu grupta yer alan turistik tüketimin önemli bir kisminda ana unsur, bir insan ile bir hayvanın rekreatif amaçlar ile bir araya gelerek iki tür arasında 
fiziksel bir temasın gerçekleşmesidir. Fiziksel temasta yer alan turist için kullanım tamamen masum ve deneyim amaçlı olsa da ürünün bir parçasını oluşturan hayvanın hazır oluşunu sağlayan süreç masum değildir. Özellikle vahşi hayvanların ürün olarak sunulduğu deneyimler son derece acılı süreçleri ve sonları içermektedir. Örneğin: Hindistan'da ve Tayland'da yavru iken annelerinden ayrılarak "Phajaan" adı verilen çok acılı bir eğitim sürecine tabi tutularak eğitilen filler vücut yapıları insan taşımaya uygun olmamasına rağmen turistleri gezdirmek amaciyla kullanılmaktadırlar. Gezinti veya gösteri yapmadıklarında ise zincirlenmiş halde tutulmaktadırlar (World Animal Protection, 2017) Dünya genelinde yük ve binek hayvanı olarak bilenen develerin Türkiye'de düzenlenen turlarda turistleri gezdirmek amaciyla kullanımı yaygın olarak görülmektedir. Kapadokya, Muğla-Fethiye'de Kayaköy öreni ve Likya yolunun develer ile gezmek için turistler yoğun talep göstermektedirler. Hatıra fotoğraflarında sahne olarak kullanılan kaplanlar bu grupta yer alan bir diğer hayvan kullanımı olarak karşımıza çıkmaktadır. Tayland, Avustralya, ABD, Meksika ve Arjantin gibi ülkelerdeki cazibe merkezlerinde fotografik sahne olarak kullanılan tutsak kaplanlar yaşamları boyunca ağır zulümler ile karşı karşıya kalmaktadırlar. Kaplan yavruları genellikle birkaç haftalık olduklarında annelerinden alınmakta ve esaret altında yetiştirilmektedirler. Bu süreçte kaplanların turistler için güvenli hale getirilmesi amaciyla köpek dişleri ve pençeleri sökülmekte, kontrol edilebilmeleri için zalimce ve sert eğitim yöntemleri uygulanmaktadır. Fotoğraf çekimleri için çok büyük olan yavrular ise öldürülebilmektedirler (World Animal Protection, [WSPA], 2014, s.5). Benzer bir vahşi hayvan kullanımını ise özellikle Güney Afrika, Zimbabve ve Zambiya ve Mauritius'ta yaygin olarak görülmektedir. Aslanlarla yürüme ve aslanlarla fotoğraf çekme olanağ1 için yavrular, birkaç haftalık iken annelerinden alınarak ve turistler ile fotoğraf çekmeye hazır olana kadar yetiştirici tarafından sık sık ele alınarak, dokunulurlar. Sık sık dokunulan bu yavrular kronik stres ve uykusuzluk nedeniyle tüylerini kaybedebilir, ishal ya da diğer hastalıklara yakalanabilirler. Aslanların turistler ile fotoğraflarının çekilebilmesi veya aslan yürüyüşleri için yeterince uyumlu hale gelebilmeleri için uyuşturulduğu ve istismar edildiği de bilinmektedir (WSPA, 2014, s.6).

Bu başlık altında yer alan "hatıra amaçlı konserve avcılığı" hayvanların yaşam hakkını elinden alan en acımasız ve sorunlu kitleyi oluşturan turistler- 
dir. Birçok uluslararası avcı, öldürdükleri hayvanları hatıra olarak getirip evlerinin duvarlarında veya raflarında sergiledikleri "hatıra avına" katılmak için Güney Afrika'ya seyahat etmektedir. Neredeyse tüm yabani türler, hatta Afrika aslanları ve filleri gibi nesli tehdit altındaki türler bile hatıra avcılığı için kullanılmaktadır. Konserve avcılığı, "konserve avlanma kampları" adı verilen çitlerle çevrili muhafazalı alanlarda esaret altına alınarak beslenen aslanların hatıra avcıları tarafından öldürülmek için bekletilmesidir. İnsanlar tarafından yetiştirilen ve besleme yapılan esir hayvanlar avcılardan kaçmadığ1 için savunmasızca öldürülmektedir (FOUR PAWS, 2020; WSPA, 2014, s.6)

I.B. Doğal Yaşam Alanında Hayvanlar ile Doğrudan Temas sekmesini incelediğimizde, turistik ürünün bir parçası olarak doğal ortamında bulunan hayvanların aslında yine metalaştııllarak kullanılması söz konusudur.

I.B.1. Doğal Ortaminda Hayvanlar ile Yikıcı Olmayan Doğrudan Temas grubunda turistler hayvanların yaşamlarını sürdürdüğü doğal ortamda doğa temelli turizm faaliyetleri, ekoturizm, vahşi yaşam ya da yaban hayatı turizminde yer almak suretiyle hayvanlarla doğrudan temas edebilmektedirler. Turizmde, ekoturizm gibi seyahat türlerinin (belirli turizm türlerine özgü olmaması gerektiği halde) hayvanlara karşı diğerlerine göre daha derin hassasiyetleri olacağı beklentisi vardır (Fennell, 2006, s. 184). Modern kentlilerin, doğal ortamında yaban hayatı ile ilişki kurma arzusuyla motive eden vahşi yaşam turizmi, giderek "büyüyen bir küresel endüstri" haline gelmiştir. Bu grupta yer almayı bilinçli olarak tercih eden turistler, hayvanlarla doğrudan temas eden kitleler arasında hayvan hakları ve etiği noktasında nispeten en az yıkıcı olanlardır. Ancak her şeye rağmen eko-turizm ve yaban hayatı turizminin; doğal hayatı, çevreyi koruduğu, hatta geliştirdiği veya çok az zarar verdiği gibi iddiaların geçerliliği, birçok belirleyici koşulun varlığına veya yokluğuna bağlıdır (Erdoğan, 2016, s.82). Yoğun eko-turist baskısı ile yaban hayati üzerinde çevresel stres faktörlerinin artması nedeniyle yaban hayvan göçü ve davranış bozuklukları ortaya çıkmakta doğaya bırakılan çöpler ve yapılan beslemeler nedeniyle hayvanlar yaşamlarını sürdürmek için gerekli olan öz beslenme yeteneklerini kaybetmektedirler (Kandır, 2017, s.7). Yaban hayatı turizmi dünya çapında milyonlarca ziyaretçiyi çektiğinden, özellikle koruma altındaki türler için bir tehdit oluşturmaktadır. Yaban hayatına dayalı turizm faaliyetlerinde yer alan turistlerin "yıkıcı" niyetleri olmasa dahi genellikle bu hayvanlar için olumsuz sonuçlara yol açabileceğini gösteren çok 
sayıda kanıt vardır. Bu olumsuz etkiler, yaban hayatı davranışının veya fizyolojik durumun bozulması ya da habitat değişikliğinden kaynaklanabilir (Higginbottom, Green ve Northrope, 2003, s.2).

I.B.2. Doğal Yaşam Alanında Hayvanlar ile Yıkıcı Doğrudan Temas grubu hayvan hakları ve hayvan etiği konusunda en sorunlu alanlardan birini teşkil ettiği düşünülmektedir. Bu grupta turistlerin hareketliliğini sağlayan av turizmi, "zevk için öldürme" yoluyla bir hayvanın doğuştan gelen ve 'yaşamın öznesi olmasından' kaynaklı olan yaşama hakkının yok edilmesine olanak sağlamaktadır. Var oluştan gelen "yaşam hakkının yok edilmesi" pek çok hayvan hakları savunucusuna göre temel etik sorunlardan biridir. Bir av s1rasında hayvanların öldürülmesi için ister faydacı, ister yaşam ve ölümün şiddetli gerçeğine merhameti aşan, ister derin bir ruhsal deneyim olsun çeşitli nedenler verilmiştir (Tickle ve Essen, 2020, s.2). Kimi çevre etiği savunucuları, avlanmanın bazı türlerin sayısını kontrol edebilmek için etkili bir araç olarak eko-sistemin dengesini korumaktaki faydalarına işaret etmektedirler. Ancak bu, her türlü cinayet için geçerli olan dışsal, faydacı bir gerekçedir. Çevreci yaklaşımda, rekreasyonel avlanmayı zevkli, isteğe bağlı bir aktivite olarak haklı çıaracak hiçbir şey yoktur (Cohen, 2014, s.6)

II. Dolaylı Temas. Dolaylı temas kapsamında baktı̆̆ımızda turistlerin hayvan ile temasının, gözlemleyici/izleyici rolü üzerinden gerçekleştiği görülmektedir. Tüketim, hayvanlar ile görsel veya işitsel temasın gerçekleştirildiği etkinlik türlerini içerebilmektedir. Örneğin dalış turizmi gerçekleştiren turistlerin ana motivasyonları balıkları beslemek, avlamak veya balıklara dokunmak değil su altı dünyasını izlemektir ve su altı dünyası içinde yer alan hayvanlar ile dolaylı bir temas söz konusudur. Hayvanlar ile direk temasın olmadığı, ancak turistlerin gerçekleştiği turizm türü/faaliyeti ile ilgili ortamlarda hayvanların da yer alması dolaylı temas olarak ifade edilebilir.

Şemada yer alan “Dolaylı Temas" “Doğal Yaşam Alanında Hayvanlar İle Yıkıcı Olmayan Dolaylı Temas" ve "Doğal Yaşam Alanından Edilmiş Hayvanlar İle Dolaylı Temas" olarak iki gruba ayrılmaktadır. "Doğal Yaşam Alanından Edilmiş Hayvanlar İle Dolaylı Temas" ise "Yıkıcı Olmayan ve Yıkıcı Temas" olarak ele alınmaktadır.

\section{II.A. Doğal Yaşam Alanında Hayvanlar ile Yıkıcı Olmayan Dolaylı Te-} mas grubu hayvanlara herhangi bir zarar verme niyeti olmaksızın hayvanlar ile doğal ortamlarında dolaylı yollardan temas etme niyetinde olan turist kitlesini ve turizm faaliyetlerini kapsamaktadır. Turizm faaliyetleri açısından 
hayvanlara en pozitif yaklaşımı içeren hareketliliğin bu grupta yer aldığı söylenebilir. Hayvanların doğal ortamlarından koparılmamaları, insanlar tarafından direk olarak yaşam haklarını tehdit eden turizm türlerini ve turizm faaliyetlerini içermemesi önemli bir noktalardır. Bu grup altında ele alınabilecek turizm hareketliliklerini, eko-turizm, balina ve yunus gözlemciliği, dalış turizmi, kuş gözlemciliği, safari ve milli park ziyaretleri ile örneklendirmek mümkündür.

Balina ve yunus ve kuş gözlemciliği dünya genelinde artık eko-turizm endüstrisinin en hızlı büyüyen sektörü haline gelmiştir. Türkiye, zengin biyoçeşitlilik değeriyle düzenli görülen 400 kuş türüne sahiptir (World Wide Fund for Nature [WWF], 2019, s.11) ve kuş gözlemcilerini, avituristleri çekmektedir. Gözlemcilik, önemli eğitim ve koruma yararları olan zararsız bir etkinlik olarak görülmekle beraber gözlemciliğin kasıtsız olarak neden olduğu hasarlara ilişkin artan endişeler de bulunmaktadır. Kuş gözlemciliğinin olumsuz etkileri arasında, nesli tehlike altındaki türlerin rahatsız edilmesi, üreme, kuluçka dönemlerinde kuşların rahatsız edilmesi, ziyaretçilerin yarattığı çevre kirliliği nedeniyle doğal döngünün bozulması gibi problemler sıralanabilir (Çakıcı ve Harman, 2006, s.63). Yine Akdeniz kıyılarında da iri başlı deniz kaplumbağası ve yeşil deniz kaplumbağası türlerinin bıraktığı yumurtalardan yavru çıkışı gözlemciliği için özellikle Dalyan'daki İztuzu ve Belek sahilleri turistlerin yoğun ilgisini çekmektedir. Hayvanların beslenme ve üreme alanları olan bu bölgelerde çevreye duyarlı ziyaretlerin yapılması ve ziyaretçilerin bilgilendirilmesi önemlidir (Güzel, 2012, s.41). Sivil toplum örgütlerinin de sosyal farkındalık arttırabilmek için bu alanda önemli bir rol üstlenerek çalışmalar yaptığı da bilinmektedir.

II.B. Doğal Yaşam Alanından Edilmiş Hayvanlar ile Dolaylı Temas. Bu grupta yer alan hayvanların turizm endüstrisi içinde farklı şekilde ürüne dönüştürüldüğü görülmektedir. Bunun temel nedenlerinden biri, günümüzde endüstrileşmiş ve doğadan uzaklaşmış modern kentlerde yaşamak zorunda kalan insanların, doğal hayata ve onun önemli bir parçası olan hayvanlara duyduğu merakın ve özlemin artmasıdır. İnsanlar kendi ihtiyaçlarının yanı sıra özellikle çocuklarının doğal yaşamın parçası olan vahşi hayvanları, böcekleri, sürüngenleri sadece kitap ve görsel medyadan değil birebir görerek, hissederek tanımalarını istemektedirler. Bu anlaşılabilir bir güdüdür. Bu başlık altında yer alan hayvan kullanımı insanların yaşadıkları ya da erişebilecekleri mekanlarda, duydukları bu merak ve özlemin giderilmesine yönelik 
düzenlemelerdir. Hayvanların bu kapsamda sergilenmek, eğlence faaliyetlerinde kullanılmak, amacıyla doğal ortamından koparılarak fiziksel olarak k1sttlanarak veya tümüyle hapsedilerek turizm faaliyetlerinde kullanıldığ 1 ve turistlerin aslında birer izleyici rolü içinde yer alarak hayvanların tüketimini destekledikleri görülmektedir. Aslında en sevdiğimiz hayvanları esir tutan endüstrileri desteklemek için büyük bir turizm ekonomisi yaratılmaktadır.

II.B.1. Doğal Yaşam Alanından Edilmiş Hayvanlar ile Yıkıcı Olmayan Dolaylı Temas. Bu grupta yer alan kullanimlar daha masum görünen hayvanat bahçeleri, kelebek bahçeleri, sığınaklar (ayı, fil, aslan, orangutan, yunus koruma alanları) akvaryumlardır. Bu grupta hayvanların neslini koruma amacı ile planlanmadığı sürece hayvanların yaşam haklarını ellerinden almasa da eğlence faaliyetleri içinde kullanılmak üzere acılı eğitim süreçleri içermese de yine de hayvanları doğal yaşamlarından kopartmakta ve esaret altında yaşatmaktadır. Bu merkezlerde, tesislerde esaret altında tutulan birçok hayvan, doğal ortamlarından ve sosyal yapılarından mahrum kalmanın bir sonucu olarak anormal davranışlar sergilemektedirler (Wildlife Rescue, t.y.)

Gerçekte, hayvanat bahçeleri ve akvaryumlar eğitici ve korumaya yönelik görünmelerine rağmen hayvanların ihtiyaçlarından çok ziyaretçilerin ihtiyaçları ve istekleri göz önünde bulundurularak tasarlanmıştırlar (Wildlife Rescue, t.y.). Hayvanat bahçeleri kendilerini turistik yerler olarak tanitırlar ve bölgesel turist broşürlerinde hayvanat bahçeleri turistik bir cazibe merkezi olarak vurgulanırlar (Beardsworth ve Bryman, 2001, s.84).

Yaban hayatı turistik çekim alanlarından biri olan sığınaklar ise hayvanların refahlarını iyileştirmek amaciyla diğer tutsak kurumlardan hayvanları temin etmektedirler. Sığınaklarda gerçekleşen temasın yıkıcı olarak değerlendirilmemesi bu alanların ziyaretinde belirlenen ilkeler nedeniyledir. Tutsak hayvanlar olmalarına rağmen örneğin fil barınaklarında turistlerin fillere binmesine veya gösterilere katılmasına, aslan barınaklarında yavruların tutulmasına, orangutan ve ayı barınaklarında bu hayvanları içeren şovlara izin verilmemektedir (Moorhouse, Dahlsjö, Baker, D'Cruze ve Macdonald, 2015, s.6)

Son dönemde hayvanat bahçeleri yerine bio-parkların ön plana çıkması hayvan refahını ön planda tutan bir algıya sahip olmalarından kaynaklanmaktadır. Değişen algı ile birlikte hayvanların klasik kafeslerde sergilenmesi yerini hayvan refahın ve standartlarını iyileştirmeyi amaçlayan doğal sergi- 
lemeye bırakmaktadır. Bu değişimin nedeni, eski sistemlerde sergilenen tutsak hayvanlarda birçok davranışsal ve fizyolojik sorunların açık şekilde belgelenmiş olmasıdır (Davey, 2006; Farrand, Hosey ve Buchanan-Smith, 2014).

Bio-parklarda, sirkler ve yunus havuzlarında olduğu gibi herhangi bir gösteri ya da eğlence amacıyla hayvan kullanımı söz konusu değildir. Aynı şekilde hayvanlara verilen uzun süreli eziyet ve işkence içeren eğitimler, küçük kafeslerde devam eden hapsedilme durumları çok büyük oranda ortadan kaldırılmıştır. Bio-parklar günümüzde hayvan nesillerin sürdürülmesine destek olarak şekilde tasarlanmaktadır (Hosey, Melfi ve Pankhurst, 2013; Dahlan ve Jiwan, 2000; Ozsule 2002)

II.B.2. Doğal Yaşam Alanından Edilmiş Hayvanlar ile Yıkıı Dolaylı Temas. Bu grupta yer alan faaliyetlerde, hayvanların yaşam haklarının ellerinden alındığı eğlence ürünleri haline getirildiği görülmektedir. Eğlence endüstrisi çok çeşitli hayvan kullanımlarını kapsadığından, yine çok çeşitli hayvan kullanımı ve istismarı örnekleri üretmiştir. Eğlence bir lüks olduğu için, insan olmayan hayvanların bu şekilde kullanılması birçok eleştirmen tarafından çağdaş hayvan kullanımlarının en az haklı gerekçeye sahip olanları olarak nitelendirilir (Waldau, 2011, s.32). Temalı deniz parkları, yüzlerce tür deniz canlısının doğal ortamında koparılarak kapatıldı̆̆ı akvaryumlar, at yarışları, köpek yarışları, köpek ve horoz dövüşleri, deve ve boğa güreşleri, köpek-kedi güzellik yarışmaları, yaban hayvan çiftlikleri gibi doğal ortamından koparılmış ve metalaştırılmış hayvanlara dayalı turistik ürünler bu kapsamda değerlendirilebilir. Hayvan severler(!)" hayvanları daha yakından görebilsinler, eğlensinler, adrenalin ihtiyaçların karşılasınlar diye hayvanlar acılı eğitim süreçlerinin yanı sıra dürtüklenir, bağlanır, aç bırakılır ve uyuşturulurlar (Meek, 2019).

Dünyanın birçok farklı ülkesinde yer alan yunus ve orkalar tutsak tutuldukları deniz parkları ve akvaryumlarda normal sosyal ve çevresel etkileşimlerden yoksun kalmaktadır. Hayvanlar doğal içgüdülerine ters düşen aşağ1layıcı numaralar yapmaya zorlanmakta ve psikolojik rahatsızlık belirtileri göstermektedirler (People for the Ethical Treatment of Animals (PETA), Aquariums and marine parks, t.y; Wildlife Rescue, t.y.). Ülkemizde yunus parklarının kuruluşuna ilişkin ulusal mevzuatta hiçbir hüküm bulunmamakta ve bu tesisler belediyelerin yetkisi olmamasına rağmen belediyelerden aldıkları ruhsatla çalışmaktadırlar. Parklarda tutsak edilen hayvanlar ithal edildiği 
gibi Türkiye sularından yakalanması yasak olmasına rağmen kaçak bir şekilde avcılığın yapıldığı bilinmektedir (Biltekin, 2020, s.13) Yaban yaşam çiftlikleri bu grupta yer alan sorunlu çekim merkezlerindendir. Cayman Adalarında koruma ve araştırma amaçlı olarak işletildiği iddiasında olan Cayman Kaplumbağa Çiftliği ülkenin en çok ziyaret edilen turistik cazibe merkezidir. Her yıl kaplumbağalarla fotoğraflarını çektirmek için gelen yüzbinlerce ziyaretçinin farkında olmadığı şey, aynı zamanda, nadir kaplumbağaların, Caymans'da geleneksel bir yemek olan etleri için öldürülmek üzere esaret altında tanklar içinde yoğun kaplumbağa yetiştirildiği bir çiftliktir (Bale, 2017; World Society for the Protection of Animals,[WSPA], 2013).

Ülke ülke gezen ve medyada oldukça geniş yer tutan pek çok ünlü sirkte, hayvanlar fiziksel ceza tehdidi altında zorla oyunlar yapmaya zorlanmakta, gösteriler dışında ise küçük, kirli kapalı muhafazalarda zincirlenmiş olarak yaşamaktadırlar. Bu merkezlerde birçok hayvan ölene kadar performansa zorlanmaktadır (PETA, Animals used for entertainment, t.y). Safkan at yarışlarında seyirciler eğlenirken atlar canları için koşmaktadırlar. Atlar, sıklıkla kırbaç hatta yasadışı elektrik şoklama cihazlarının tehdidi altında, sık sık yaralanmalara ve hatta akciğerlerden kanamaya maruz kalacak kadar yüksek hızlarda koşmaya zorlanmaktadırlar (PETA, Horse racing, t.y.). Bu grupta yer alan önemli yıkıcı temaslardan bir diğeri İspanya'nın Pamplona şehrinde San Fermin Festivalinde düzenlenen boğa koşularıdır. Koşu sonrası ise arenada matadorlar ile boğa güreşi için karşılaştırılan boğaların çoğu öldürülmektedir. Bu etkinliklerin devamlılığını sağlayan ise büyük ölçüde turizmden elde edilen gelirlerdir. Her yıl binlerce turist, Ernest Hemingway'in Fiesta romanında anlatılan geleneksel boğa koşusuna katılma heyecanını deneyimlemek için insan oraya gitmektedir (https://www.spain.info/en/calendar/fiestas-san-fermin/).

$\mathrm{Bu}$ grupta yer alan deve güreşleri için Selçuk, Bodrum ve Kuşadası gibi turistik yörelerimizde son ylllarda yerli ve yabancı turistleri cezbetmek için büyük deve güreşi organizasyonları için çalışmalar yürütülmektedirler (Yılmaz ve Ertuğrul, 2015, s.171). Yılmaz ve Ertuğrul (2015), Çulha (2008) deve güreşlerinin kültürel mirası olduğunu develerin evlat gibi görülüp özen gösterildiğini ifade etmektedirler. Atasoy ve Özbaşer (2014) deve güreşlerinin gereken önlemler alındığında hayvan refahı üzerine olumsuz etkiler yaratmayacağını, doğru bilgilendirmeyle Türkiye'nin tanıtılmasına olumlu katkı 
sağlayacağını belirtmektedirler (s.90). Ancak dövüştürülen develerin sırtlarına ve başlarına süslemelerden oluşan ağır bir semer ve çeşitli örtüler konulduğu ve ağızlarının birbirlerine ısırmamaları amacıyla bağlandığı görülmektedir. Güreşler develerin kızgınlık gösterdiği aylar arasında yapılmakta ve develerin birbirlerine öfkelenmelerini sağlamak ve kıskançlık yaratmak için dişi bir deve arenada dolaştırılmaktadır. Develer dövüşmek istemezlerse demir çubuklarla veya tahta sopalar ile ayaklarına vurulmakta, iğne batırılmaktadır (Kalkandelen, 2019; Yıldırım, 2014).

\section{Tartışma ve Sonuç}

Hayvanlar bu dünyanın vazgeçilemez bir parçasıdır. Özellikle son 50 senedir dünya üzerinde yaşayan yüz binlerce canlı türü olmasına rağmen, dünya sadece insan türüne fayda sağlayacak şekilde sömürülmektedir.

Turizm akademisyenleri uzun yıllardır turizm endüstrisinin sürdürülebilir olması için çaba sarf etmekte bu alanda binlerce çalışma ortaya koymaktadırlar. Turizm endüstrisinde son yıllarda hayvanların refahı veya hayvan hakları üzerine yapılmış çalışmaların sayısının artması ve hayvanların turizm çalışmalarında artan merkezileşmesi şüphesiz çok değerlidir, çünkü turizm karşılaşmalarını sadece bir insan olgusu olarak teorileştirmenin baskın pratiğini sarsmaktadır (Valtonen, Salmela ve Rantala, 2020, s.2). Ancak, batı toplumlarında ve turizm endüstrisinde insan merkezciliğin egemenliği göz önüne alındığında, hayvan etiğinin turizm etiği içinde özel bir alan olarak daha da geliştirilmesi zorunludur (Winter, 2020, s.2). Bu bağlamda Türk literatüründe sınırlı sayıda olan turizm endüstrisinde hayvan kullanımı ve hayvan etiği alanında farklı çalışmalara ihtiyaç olduğu ifade edilmelidir.

Temas amacı ve türü ne olursa olsun turistlerin gittikleri yeni destinasyonlarda daha önce görmedikleri ve merak ettikleri hayvanları görmek, temas gerçekleştirmek istemeleri oldukça doğaldır. Bu merak incelendiğinde içerisinde aslında bir talebi de barındırmaktadır. Turistlerin yerel hayvanlara olan merakı; eğitimsiz ve yoğun maddi kaygılar ile turistlere deneyim sağlamaya çalışan yerel halkın o coğrafyada bulunan hayvanları düşüncesizce metalaştırılmasına neden olmaktadır. Ne yazık ki, hayvanları seven pek çok turist, sırf gizli zulmün farkında olmadıkları için hayvanların acı çekmesine katkıda bulunabilmektedir. Aslında, bu durum turistlerin, yaban hayatın kabul edi- 
lebilir kullanımının nelerin oluşturduğu konusunda hakem olarak hareket etmelerini gerektirmektedir. Ancak turistler bu rol için yeterince donanımlı değildirler. İnsani değerler, gruplar ve milletler arasında farklılık gösterir, hayvan refahına ve koruma faydalarına önem veren turistler bile, genellikle paradoksal olarak, yaban hayatı turizmine katılabilirler. Bu durum, turistlerin seçimlerinin olası etkilerini ölçmek için yeterince uzman olmadıklarından veya tatildeyken etik kararlarla ilgilenmek istemediklerinden olabilir (Moorhouse, D'Cruze ve Macdonald, 2017, s.9). Turistler genellikle bir hayvanla karşılaşma istekleri ile hayvanların refah maliyetleri arasında bilişsel uyumsuzluk yaşasa da çoğu, ziyaretlerinin meşruiyetini haklı çıkarabilir ve kendilerini ikna edebilirler (Winter; t.y.) Hayvanlara nasıl davranıldığının ne kadar çok farkına varırsak, onları zulüm ve acılardan o kadar çok koruyabiliriz. Seyahat ederken hayvan dostu olmak, ziyaret ettiğiniz her ülkede insanlara, kültüre, çevreye ve hayvanlara her zaman saygı göstermeniz anlamına gelmektedir ve zorlu bir süreç değildir.

İnsanın, insan olmayan diğer canlılara ve özellikle kendisi gibi hisseden, acı çeken, hatırlayan, acıkan, susayan, analık duygusu yaşayan hayvanlara çivili sopa, kırbaç, elektro şok çubuğu, kanca gibi işkence aletleri kullanılarak verilen acılı ve uzun eğitimleri neticesinde ortaya konan gösterileri satın almayı talep etmesini anlamak oldukça güçtür. Bu durum başta ahlak kavramı ve etik bilimi ile çatışma, hatta çok daha basit seviyede vicdan ile çelişmektedir. Hayvan kullanımının arkasındaki kirli durum, sürdürülebilirlik ilkesiyle de zitlaşma içerisindedir.

Araştırma kapsamında ortaya koyulmaya çalışılan "temas temelli yaklaşım” etik, ahlak ve sürdürülebilirlik iddialarından bağımsız düşünülmemelidir. Her bilimsel fikirde olduğu gibi sunulan bu yaklaşım tartı̧ılmaya ve geliştirilmeye açıktır. 


\section{EXTENDED ABSTRACT \\ Animal Use in the Tourism Industry: Non-Destructive Contact-Based Approach

\author{
Emirhan Yenişehirlioğlu- Emine Cihangir \\ Alaattin Keykubat University-Yüzüncü Yıl University
}

We do not have any significant information on when the human-animal relationship has started in history. However, it is estimated that this relationship started from the anthropogenic era, from which modern human emerged from. From the last known global ice age, which was about 16,000 years ago, until today, the human species has been obtaining most of their food and raw-material needs from animals and plants, and even anthropologists created the concept of "hunter and gatherer" to describe the economic order of that day. As the historical process progresses, the relationship $\mathrm{b}$ and animals also improve. When we look batthe industrial revolution, it can be seen that animals were frequently used in areas such as agriculture, transportation, security, hunting and communication.

Though, the usage animals by different industries like veterinary, medicine, chemistry also brings us some problems about animal rights and ethics.

Tourism is one of the most important industries in the use of animals. Although studies on animal rights and animal ethics have been conducted throughout the world for many years, it has been seen in the literature review that there is not enough work done on this subject in our country. As there are new studies on the different aspects of animal use and animal ethics in tourism, it is thought that a holistic view is needed.

Considering the current tourism types, it is necessary to examine the industry's relationship with animals under two main headings. These headings are "Direct Contact" and "Indirect Contact". For this reason, the first step of the model to be created makes a distinction over the contact type.

The tab "Indirect Contact with Animals Extracted from Their Natural Habitats" is used to express the contact of animals that are physically restricted or completely imprisoned by being detached from their natural 
environment for dia splay to humans. Zoos can be given as an example of the related statement.

The "Direct Contact With Animals From Their Natural Habitat" tab is used to indicate the tourist mass that has direct contact with animals and supports this contact with conscious choices. The direct contact mentioned in the tab covers all benefits that take away the natural life rights of animals and its also problematic in an ethical way.

When we examine the "Direct Contact With Animals In Its Natural Environment" tab, it is possible to use the animals in their natural environment as a part of the touristic product by being commodified. The only difference here is that the animal is in its natural environment where it is used or benefited from.

"Direct Contact with Animals Extracted from Their Natural Habitats in a Destructive way" tab refers to animal use an in an unnatural way such as Bull Run, Camel Ride, taking a photo with lions etc. In this concept, there is direct contact between human and animals. There are also some ethical problems in this matter.

Another tab is namas "Indirect Contact with Animals in their Natural Environment" due to contact in its natural environment without the purpose of harming the animals.

It is incomprehensible that human beings imprison other non-human creatures and especially creatures that feel like themselves, suffer, remember, get hungry and thirsty for no reason.

This situation conflicts with the es and even with the principle of sustainability at a much simpler level. The moral understanding, which is the basis of sustainability, continues its existence in animal rights as well. Animals cannot be considered separate from the nature.

Animals are an indispensable part of this world. The world is exploited in a way that only benes the human species, even though there are hundreds of thousands of species living in the World. This exploitation extends from underground mines to the atmosphere layer and also reaches beyond the borders of the earth with space mining. If there is one thing for sure, it is that the human species is greedy. Unfortunately, animals suffer the most from this greed.

Tourism academics have been striving for the sustainability of the tourism industry for many years and have produced hundreds of studies in 
this field. However, studies on the animal welfare or usage of animals in the industry are just a few, especially in the Turkish literature. In this context, it should be stated that different studies are needed in the field of the tourism industry.

This study is tried to be put forward within the scope of the research should not be considered independent from the ideas of ethics, morality, and sustainability. Like any other scientific idea, this study is also open to development.

\section{Kaynakça / References}

Adıgüzel, B. (2018). Turizmde kör nokta; hayvan hakları. Atlas International Refereed Journal on Social Sciences, 4(11), 851-868.

Akar, M. (1994). Göçebe Türkmenlerde deve güreşi ve sosyo-kültürel boyutu. I. Türk Halk Kültürü Araştrma Sonuçlarn Sempozyumu Bildirileri, II. Cilt, Ankara: Kültür Bakanlığı Yayınları.

Aşar, H. (2018). Hayvan haklarına yönelik temel görüşler ve yanılgıları. Kaygı. Uludă̆ Üniversitesi Fen-Edebiyat Fakültesi Felsefe Dergisi, 30, 239-251.

Atasoy, F. ve Özbaşer, F. T. (2014). Anadolu'da deve yetiştiriciliği ve deve güreşleri. Lalahan Hayvancllk Araştırma Enstitüsü Dergisi, 54(2), 85-90.

Bale, R. (2017). This turtle tourcentrenter also raises endangered turtles for meat, $\mathrm{Na}-$ tional Geographic. 30 Temmuz 2021 tarihinde https://www.nationalgeographic.com/animals/article/wildlife-watch-cayman-turtle-farm-welfare-controversy, adresinden erişildi.

Beardsworth, A. ve Bryman, A. (2001). The wild animal in late modernity: The case of the dissemination of zoos. Tourist Studies, 1(1), 83-104.

Bekoff, M. (2008). Increasing our compassion footprint: The animals' manifesto. Zygon, 43(4), 771-781.

Bennett, A. J. ve Ringach, D. L. (2016). Animal research in neuroscience: A duty to engage. Neuron, 92(3), 653-657.

Bern Convention. Convention on the Conservation of European Wildlife and Natural Habitats. (BERN). 30 Temmuz 2021 tarihinde https://www.coe.int/en/web/bernconvention adresinden erişildi.

Bertella, G. (2016). Experiencing nature in animal-based tourism. Journal of Outdoor Recreation and Tourism, 14, 22-26.

Biltekin F., (2020). Hayvan hakları alannnda çalışan sivil toplum örgütleri için yerel savunuculuk rehberi. Yerel İzleme Araştırma ve Uygulama Derneği. 
Bullbeck, C. (1999) The 'nature dispositions' of visitors to animal encounter sites in Australia and New Zealand. Journal of Sociology, 35(2), 129-148

Çakıcı, A. C. ve Harman, S. (2006). Kuş gözlemciliğinin önemi: Türkiye'de kuş gözlemciliğinin profili. Anatolia: Turizm Araştırmalan Dergisi, 17(2), 161-168.

Calarco, M. R. (2020). Animal studies: the key concepts. N.Y.: Routledge.

Çalık, A. Ö. Ve Çiftçi, G. (2013). Animal ethics in tourism. International Journal of Business and Management Studies, 5(1), 43-53.

Çalışkan, V. (2010). Kültürel bir mirasın coğrafyast: Türkiye'de deve güreşleri. Selçuk Efes Kent Belleği Yayınları, İstanbul: Selçuk Belediyesi Yayını.

Carr, N. ve Broom, D. M. (2018). Tourism and animal welfare. London: CABI.

Clark, B. ve Wilson, T. D. (2020). The Capitalist Commodification of Animals: A Brief Introduction. Clark, B. ve Wilson, T. D. (Der.), The Capitalist Commodification of Animals içinde (1-5). UK: Emerald Publishing Limited.

Coeckelbergh, M. ve Gunkel, D. J. (2014). Facing animals: A relational, other-oriented approach to moral standing. Journal of agricultural and environmental ethics, 27(5), 715-733.

Cohen, E. (2009). The wild and the humanized: Animals in Thai tourism. Anatolia, 20(1), 100-118.

Cohen, E. (2014). Recreational hunting: Ethics, experiences, and commoditization. Tourism Recreation Research, 39(1), 3-17.

Crang, M. (2015). Travelling ethics: Valuing harmony, habitat and heritage while consuming people and places. Geoforum, 67, 194-203.

Çulha, O. (2008). Kültür turizmi kapsamında destekleyici turistik ürün olarak deve güreşi festivalleri üzerine bir alan çalışması. Journal of Yaşar University, 3(12), 1827-1852.

Dahlan, I. ve Jiwan, M. (2000). Bio-park animals: Deer, mousedeer, porcupines and squirrels. Asian Australasian Journal of Animal Sciences, 13, 334-336.

Davey, G. (2006). Relationships between exhibit naturalism, animal visibility and visitor interest in a Chinese Zoo. Applied Animal Behaviour Science, 96(1), 93-102.

Dawkins, MS. (2004). Using behaviour to assess animal welfare. Animal Welfare, 13, 53-57.

Dilek, E. ve Küçükaltan, E. G. (2018). Hayvan odaklı turizm faaliyetlerine meta eleştirel bakış: Türkiye örneği. Anatolia: Turizm Araştırmaları Dergisi, 29(1), 112.

Doke, S. K. ve Dhawale, S. C. (2015). Alternatives to animal testing: A review. Saudi Pharmaceutical Journal, 23(3), 223-229. 
Dolmacı, N. ve Bulgan, G. (2013). Turizm etiği kapsamında çevresel duyarlllık. Journal of Yasar University, 8(29), 4853-4871.

Duffus, D. A. ve Dearden, P. (1990). Non-consumptive wildlife-oriented recreation: A conceptual framework. Biological Conservation, 53(3), 213-231.

Duncan, I. J. (2005). Science-based assessment of animal welfare: farm animals. Revue scientifique et technique-Office international des epizooties, 24(2), 483.

Erdem, C. (1998). Halk eğlencelerinden deve güreşlerinin bölgesel turizmdeki yeri. Türk Halk Kültürü Araştırmaları, Kültür Bakanlığı Yayınları, s.21-30.

Erdoğan N. (2016). Ekoturizm ve yaban hayatt. Türkiye Klinikleri Animal Nutrition and Nutritional Diseases Special Topics, 2(1), 76-84.

Essen, E. V., Lindsjö, J. ve Berg, C. (2020). Instagranimal: Animal Welfare and Animal Ethics Challenges of Animal-Based Tourism. Animals, 10(10), 1830.

Farrand, A., Hosey, G. ve Buchanan-Smith, H. M. (2014). The visitor effect in petting zoo-housed animals: Aversive or enriching?. Applied Animal Behaviour Science, 151, 117-127.

Fennell, D. A. (2006). Tourism ethics. Clevedon: Channel View Publications.

Fennell, D. A. (2012). Tourism and Animal Rights. Tourism Recreation Research, 37(2), 157-166.

Fennell, D. A. (2013). Tourism and animal welfare. Tourism Recreation Research, 38(3), 325-340.

FOUR PAWS, (2020). Born to be killed for canned "trophy" hunting, 30 Temmuz 2021 tarihinde https://www.four-paws.us/campaigns-topics/topics/help-for-bigcats/canned-lion-hunting, adresinden erisildi.

Fraser, D. (2009). Assessing animal welfare: different philosophies, different scientific approaches. Zoo Biology, 28(6), 507-518.

Güzel, Ö. (2012). Kaynak tabanlı turizm kapsamında doğal kaynakların korunmasına yönelik dalyan destinasyonunda örnek olay incelemesi: Caretta Carettalar. Turar Turizm ve Araştırma Dergisi, 1(2), 36-75.

Hall, D., Roberts, L., Wemelsfelder, F. ve Farish, M. (2003). Animal attractions, welfare and the rural experience economy. D. Hall, L. Roberts ve M. Mitchell (Der.) New directions in rural tourism içinde (ss. 90-101), N.Y.: Routledge.

Harman, S. ve Dilek, S. E. (2017). Whale and dolphin watching, and visitors' experiential responses: A qualitative study on comments in a travel forum. I.B. de Lima ve R.J. Green (Der.) Wildlife tourism, environmental learning and ethical encounters içinde (s.183-193). Cham: Springer.

Hewson, C.J. (2003). What is animal welfare? Common definitions and their practical consequences. Canadian Veterinary Journal, 44(6), 496-499. 
Higginbottom, K., 2004. Wildlife tourism: an introduction. Higginbottom, K. (Der.), Wildlife Tourism: Impacts, Management and Planning içinde (s.1-14). Altona: Common Ground Publishing.

Higginbottom, K., Green, R. ve Northrope, C. (2003). A framework for managing the negative impacts of wildlife tourism on wildlife. Human dimensions of wildlife, 8(1), 1-24.

Hosey, G., Melfi, V. ve Pankhurst, S. (2013). Zoo animals: Behaviour, management, and welfare. Oxford: Oxford University Press.

İzmirli, S. ve Yaşar, A. (2006). Veteriner Hekimliği Etiği-Hayvan Gönenci (Refahı) İlişkisi. Veteriner Bilimleri Dergisi, 22, 25-29.

Kalkandelen Z. (2019) Yüzünüz kızardı mı?. Cumhuriyet. https://www.cumhuriyet.com.tr/yazarlar/zulal-kalkandelen/yuzunuz-kizardi-mi-1240222, Yayın Tarihi: 10.02.2019, Erişim Tarihi: 16.02 .2021

Kandır, E. H. (2017). Ekoturizmin diğer yüzü "yaban hayatı ve ekoturizm. Ayrmtı Dergisi, 5(51), 5-9.

Kılıçııran, M. N. (1987). Ege'de kış turizminin kurtarıcısı: Deve güreşleri. III. Milletlerarası Türk Folklor Kongreleri Bildirileri, (s.125-147). Ankara: Başbakanlık Basımevi.

Kinder E. (2019). The dark side of animal tourism. The Boar. 30 Temmuz 2021 tarihinde https://theboar.org/2019/11/the-dark-side-of-animal-tourism/ adresinden erisildi.

Kurlar Can, B., Ertaş, M., Yeşilyurt, H. ve Günlü Küçükaltan, E. (2017). The relationship between tourism and commodification: A conceptual approach. İsletme Fakültesi Dergisi, 18(2), 265-282.

Küçükaltan Günlü, E. ve Dilek, S. E. (2016). Metalaşan turizm-metalaştırlan hayvanlar: Turizmin ahlaki sorumluluğu olabilir mi?. Ankara: Nobel Akademik Yayıncllk.

Küçükaltan, E. G. ve Dilek, S. E. (2019). A Philosophical Approach to Animal Rights and Welfare in the Tourism Sector. Journal of Tourism Leisure and Hospitality, 1(1), 1-11.

Malloy, D. C. ve Fennell, D. A. (1998). Codes of ethics and tourism: An exploratory content analysis. Tourism Management, 19(5), 453-461.

Meek, T. (2019). Animals in entertainment: Is our amusement worth their suffering? Sentient Media. 30 Temmuz 2021 tarihinde https://sentientmedia.org/animalsin-entertainment/\#: :text=Many\%20species\%20of\%20animals\%20are,camels\%20within\%20the\%20entertainment\%20sector. adresinden erisildi.

Moorhouse, T. P., Dahlsjö, C. A., Baker, S. E., D'Cruze, N. C. ve Macdonald, D. W. (2015). The customer isn't always right-conservation and animal welfare 
implications of the increasing demand for wildlife tourism. Plos one, 10(10). https://doi.org/10.1371/journal.pone.0138939

Moorhouse, T., D'Cruze, N. C. ve Macdonald, D. W. (2017). Unethical use of wildlife in tourism: what's the problem, who is responsible, and what can be done?. Journal of Sustainable Tourism, 25(4), 505-516.

Moscardo, G. (2013). The role and management of non-captive wildlife in ecotourism. Ballantyne, R. ve Packer, J. (Der.), International handbook on ecotourism içinde (351-364). Cheltenham: Edward Elgar Publishing.

Newmyer, S. T. (2006). Animals, rights, and reason in Plutarch and modern ethics. N.Y.: Routledge.

Nibert, D. (2013). Animal oppression and human violence: Domesecration, capitalism, and global conflict. Columbia University Press.

Oliver, K. (2009). Animal lessons: How they teach us to be human. N.Y.: Columbia University Press.

Orams, M. B. (1996). A conceptual model of tourist-wildlife interaction: the case for education as a management strategy. Australian Geographer, 27(1), 39-51.

Özdağ, U. (2005). The turning of the tide: the evolution of ethics and contemporary moral considerations regarding nonhuman entities in American literature. Edebiyat Fakültesi Dergisi, 22(2).

Özen, A. S. (2015). Küresel zoo çeşitliliğin korunmasında önem taşıyan hayvanat bahçesi ve akvaryum birlikleri. Dumlupinar Üniversitesi Fen Bilimleri Enstitüsü Dergisi, 34, 1-8.

Özer, O. (2020). Türkiye'nin av turizmi potansiyeli konusunda bir değerlendirme. Journal of Gastronomy Hospitality and Travel, 3(1), 71-86.

Özgür, A. (2010). Hayvanlarla Yaşamı Paylaşmak. Veteriner Hekimler Derneği, 81(2), 913.

Ozsule, Z. (2002). Bioparkiss a new concept for 21st-centuryo design. The Stu study conservation and utilisation of forest resources içinde (ss. 407-416). Proceedings of the Third Balkan Scientific Conference, Sofia, Bulgaria, 2-6 October 2001. Volume II Forest Research Institute.

Painter C. (2016). Non-human animals within contemporary capitalism: A Marxist account of non-human animal liberation. Capital ve Class, 40(2), 327-345.

People for the Ethical Treatment of Animals. Animals used for entertainment. 30 Temmuz 2021 tarihinde https://www.peta.org/issues/animals-in-entertainment/, adresinden erişildi. 
People for the Ethical Treatment of Animals. Aquariums and marine parks, 30 Temmuz 2021 tarihinde https://www.peta.org/issues/animals-in-entertainment/zoospseudo-sanctuaries/aquariums-marine-parks/, adresinden erisildi.

People for the Ethical Treatment of Animals. Horse racing. 30 Temmuz 2021 tarihinde https://www.peta.org/issues/animals-in-entertainment/horse-racing-2/, adresinden erisildi.

Regan, T. (2003). Introduction: Animal rights, human wrongs: an introduction to moral philosophy. Maryland: Rowman and Littlefield Publishers.

Regan, T. (2004). The case for animal rights. Berkeley: University of California Press, (originally published, 1994).

Reynolds, P. C. ve Braithwaite, D. (2001). Towards a conceptual framework for wildlife tourism. Tourism Managementt, 22(1), 31-42.

Rollin, Bernard E. (1981). Animal rights and human morality. N.Y.: Prometheus Books.

Şafak, İ. (2003). Türkiye'deki av turizmi uygulamalarının özel avlak işletmelerine etkileri. Türkiye Ormancllk Dergisi, 4(2), 133-148.

Sandøe, P. ve Christiansen, S. B. (2013). Ethics of animal use. John Wiley ve Sons.

Sarıtaş, E. (2016). İnsan dışı hayvanlar ve adalet, Vira Verita ,2015(1), 1-18.

Savaş, T., Yurtman, İ. Y. ve Tölü, C. (2009). Hayvan hakları ve hayvan refahı: Felsefi bakış-nesnel arayışlar. Hayvansal Üretim, 50(1), 54-61.

Serpell, J. (1996). In the company of animals: A study of human-animal relationships. N.Y.: Cambridge University Press.

Shackley, M. (1996). Wildlife tourism. London: International Thomson Business Press.

Shani, A. (2009). Tourists' attitudes toward the use of animals in tourist attractions: an empirical investigation. Doctoral Dissertation, University of Central Florida, Orlando.

Shani, A. (2013). Differentiating settings of tourist-animal interactions: An anthrozoological perspective. Tourism Recreation Research, 38(1), 104-107.

Shani, A. ve Pizam, A. (2008). Towards an ethical framework for animal-based attractions. International Journal of Contemporary Hospitality Management, 20(6), 679693.

Sherry, C. J. (2009). Animal rights: A reference handbook. Santa Barbara: ABC-CLIO, LLC.

Singer, P. (1975). Animal liberation. N.Y.: Harper Collins Publishers.

Singer, P. (2011). Practical ethics. N..: Cambridge University Press.

Sjoberg, G. (2002). Sanayi öncesi kenti. A. Alkan ve B. Duru (Der. ve Çev.), 20. Yüzyıl kenti içinde (s.37-54), İmge Yayınevi: Ankara. 
Sneddon, J., Lee, J., Ballantyne, R. ve Packer, J. (2016). Animal welfare values and tourist behaviour. Annals of Tourism Research, 57, 234-278.

Snyder, J., Crooks, V. A. ve Johnston, R. (2012). Perceptions of the ethics of medical tourism: Comparing patient and academic perspectives. Public Health Ethics, 5(1), 38-46.

The Convention on International Trade In Endangered Species of Wild Fauna and Flora(CITES). 30 Temmuz 2021 tarihinde https://www.cites.org/, adresinden erişildi.

Tickle, L. ve von Essen, E. (2020). The seven sins of hunting tourism. Annals of Tourism Research, 84, 102996.

Tourism Concern. (2017). Research briefing. Animals in tourism. 30 Temmuz 2021 tarihinde https://www.tourismconcern.org.uk/wpcontent/uploads/2016/02/Animalsin-Tourism-lWeb-FINAL.pdf adresinden erişildi.

Tremblay, P. (2001). Wildlife tourism consumption: consumptive or non-consumptive?. The International Journal of Tourism Research, 3(1), 81.

Ulusoy, H. (2015). Av turizminin kırsal turizm açısından kırsal kalkınma üzerindeki etkisinin irdelenmesi. Türk Bilimsel Derlemeler Dergisi, 8(2), 74-80.

Valtonen, A., Salmela, T. ve Rantala, O. (2020). Living with mosquitoes. Annals of Tourism Research, 83, 102945.

Waldau, P. (2011). Animal rights: What everyone needs to know. N.Y.: Oxford University Press.

Wildlife Rescue, Animals in Entertainment, Cruel Spectacles. 30 Temmuz 2021 tarihinde https://wildlife-rescue.org/services/advocacy/animals-in-entertainment/, adresinden erişildi.

Winter, C. (2020). A review of animal ethics in tourism: Launching the annals of tourism research curated collection on animal ethics in tourism. Annals of Tourism Research, 84, 102989.

Winter, C. (T.Y). Curated Collection: Animal ethics in tourism. Annals of Tourism Research.

World Animal Protection. (2014). The show can't go on. 30 Temmuz 2021 tarihinde https://www.worldanimalprotection.org/sites/default/files/media/int files/showcannot-go-on-animals-entertainment.pdf adresinden erișildi.

World Animal Protection. (2017). Taken for a ride. The conditions for elephants used in tourism in Asia. 30 Temmuz 2021 tarihinde https://www.worldanimalprotection.org/sites/default/files/media/int files/taken for a ride.pdf adresinden erișildi. 
World Society for the Protection of Animals. (2013). The cayman turtle farm: a continued case for change. . 30 Temmuz 2021 tarihinde https://www.worldanimalprotection.org.uk/sites/default/files/media/uk files/documents/cayman turtle farm a continued case for change.pdfadresinden erișildi.

World Travel ve Tourism Council. (2019). The Economic Impact of Global Wildlife Tourism. 30 Temmuz 2021 tarihinde https://wttc.org/Portals/0/Documents/Reports/2019/Sustainable\%20Growth-Economic\%20Impact $\% 20$ of\%20Global\%20Wildlife\%20Tourism-Aug\%202019.pdf?ver=2021-0225-182802-167

World Wide Fund for Nature. (2019). Türkiye Üreyen Kuş Atlası Raporu. 30 Temmuz 2021 tarihinde https://d2hawiim0tjbd8.cloudfront.net/downloads/turkiye ureyen $\mathrm{ku}$ atlas.pdf adresinden erișildi.

Yakut, İ. (2009). Ege'nin deve güreşi şenlikleri. İzmir: İzmir Büyükşehir Belediyesi Kent Kitaplığı.

Yaşar, A. ve Yerlikaya, H. (2004). Dünya'da ve Türkiye'de hayvan haklarının tarihsel gelişimi. Veteriner Bilimleri Dergisi, 20(4), 39-46.

Yiğit, A., Çağlar Sinmez, Ç. ve Aslım, G. (2015). Türkiye'de deney hayvanı kullanmaya yetkili kişilerin hayvan kullanımına yönelik tutumları. Kafkas Üniversitesi Veterinerlik Fakültesi Dergisi, 21(6), 885-892.

Yıldırım, T. (2014) Deve güreşi yasaklansın. Hürriyet. 30 Temmuz 2021 tarihinde https://www.hurriyet.com.trlege/deve-guresi-yasaklansin-27786546 adresinden erișildi.

Yılmaz, O. ve Ertuğrul, M. (2015). Türk kültüründe deve güreşleri. Bitlis Eren Üniversitesi Sosyal Bilimler Dergisi, 4(1), 157-174.

Yount, L. (2008). Animal rights. N.Y: Infobase Publishing.

\section{Kaynakça Bilgisi / Citation Information}

Yenişehirlioğlu, E. ve Cihangir, E. (2021). Turizm endüstrisinde hayvan kullanımı: Yıkıcı-yıkıcı olmayan temas temelli yaklaşım. OPUSUluslararası Toplum Araştırmaları Dergisi, 18(41), 3881-3917. DOI: 10.26466/opus.925503. 